\title{
Structure and dynamics of demersal assemblages on the continental shelf and upper slope off Ghana, West Africa
}

\author{
Kwame A. Koranteng* \\ Marine Fisheries Research Division, PO Box BT-62, Tema, Ghana
}

\begin{abstract}
Using two-way indicator species analysis and detrended correspondence analysis, species on the continental shelf and upper slope of Ghana were classified into 6 assemblages. The structure of the assemblages is determined primarily by depth and type of sediment on the seabed. There are clear faunal discontinuities around 30-40, 100 and $200 \mathrm{~m}$ depth. The dynamics of the assemblages are influenced by physico-chemical parameters of the water masses, mainly temperature, salinity and dissolved oxygen, which are periodically modified by the seasonal coastal upwelling that occurs in the area. The observed changes in the composition and relative importance of species in the assemblages can be related to increased fishing activity and environmental forcing.
\end{abstract}

KEY WORDS: Species assemblages $\cdot$ Structure and dynamics $\cdot$ Continental shelf and slope $\cdot$ Ghana

\section{INTRODUCTION}

In fisheries, defining the aggregation of species in the ecosystem is the basis for managing species by the management unit approach (Tyler et al. 1982). Caddy \& Sharp (1986) also pointed out that such studies are necessary to gain a better understanding of multispecies stocks and for the management of these stocks. For such reasons, the structure of species assemblages for several exploited fish stocks around the world has been established. Examples are in the Narragansett Bay, USA (Oviatt \& Nixon 1973), Scotian shelf, Canada's Atlantic coast (Mahon 1985), southern Gulf of Mexico (Yáñez-Arancibia et al. 1985), Gulf of Carpentaria, Australia (Blaber et al. 1994), Congo, Gabon and Angola in south-west Africa (Bianchi 1992), and the North-western Indian Ocean and East Africa (Bianchi 1992). In the Gulf of Guinea, West Africa, Fager \& Longhurst (1968) and Longhurst (1969) established the assemblage structure of demersal species on the conti-

*E-mail: kwamek@africaonline.com.gh nental shelf using data from the Guinean Trawling Survey (Williams 1968).

In the last 3 decades, significant changes have occurred in the biological and physical components of the Gulf of Guinea marine ecosystem and in nearshore forcing factors that could have an effect on species aggregations in the sub-region (Koranteng 1998). The most important recorded changes are the decline and subsequent recovery of the round sardinella Sardinella aurita populations (Pezennec 1995), the proliferation and subsequent decline of triggerfish Balistes capriscus (Ansa-Emmim 1979, Koranteng 1984, Caverivière 1991) and the increase in abundance of cuttlefish Sepia officinalis and globefish Lagocephalus laevigatus (Ramos et al. 1990, Koranteng 1998). Studies of fish communities have shown that some natural and anthropogenic factors could induce changes in the structure of species assemblages and affect the general wellbeing of fishery resources.

The objectives of this paper are to: (1) establish assemblage units of demersal fish species on the continental shelf and upper slope off Ghana; (2) establish the factors that determine the structure of these assem- 
blages; and, (3) assess the impact of environmental forcing and of fishing on the structure and dynamics of the assemblages.

Study area. The study area is the continental shelf and upper slope off Ghana, West Africa (Fig. 1). The coastline of Ghana, measuring about $536 \mathrm{~km}$ long, stretches from longitude $3^{\circ} 06^{\prime} \mathrm{W}$ to $1^{\circ} 10^{\prime} \mathrm{E}$ and lies between latitudes $4^{\circ} 30^{\prime}$ and $6^{\circ} 6^{\prime} \mathrm{N}$. The continental shelf varies in width between $\sim 13$ and $80 \mathrm{~km}$ (Williams 1968, Koranteng 1998), with the widest point in the middle. The shelf usually drops sharply just after the $75 \mathrm{~m}$ depth contour. The area of the continental shelf to the $200 \mathrm{~m}$ depth contour is $23700 \mathrm{~km}^{2}$ (Koranteng 1984).

The ocean floor on the continental shelf off Ghana has distinct areas of mud, hard rocks and mixed deposits. There is a belt of soft, muddy substrate in shallow waters down to $\sim 30 \mathrm{~m}$ depth, followed by a wide area of mixed to hard bottom type (Fig. 1, Williams 1968). Generally, the area beyond $75 \mathrm{~m}$ depth is not safe for trawling, except towards the western side (Rijavec 1980, Koranteng 1984) where vessels can trawl in waters deeper than $100 \mathrm{~m}$.

Situated in the western Gulf of Guinea, a subsystem of the Guinea Current Large Marine Ecosystem (Binet \& Marchal 1993, Sherman 1993), the continental shelf waters off Ghana experience 2 seasonal periods of coastal upwelling (major and minor) each year, with differing duration and intensities. During the upwelling, sea surface temperature (SST) drops, surface salinity increases, and dissolved oxygen decreases (Mensah \& Koranteng 1988). The major upwelling (long cold season) occurs between July and September when SST (usually $\sim 27$ to $29^{\circ} \mathrm{C}$ ) falls below $25^{\circ} \mathrm{C}$. The minor upwelling (short cold season) normally lasts for only about 3 wk (occurring anytime between Decem- ber and March). In between the cold seasons are warm seasons during which SST is relatively high and a strong thermocline is formed in continental shelf waters.

Koranteng (1998) showed that the period between 1963 and 1992 could be broken down into 3 climatic periods, each of which had distinct environmental characteristics in the Gulf of Guinea. In the first period (i.e. before 1972), sea temperatures (surface and bottom) were relatively high, salinity was low and the thermocline was below its long-term average depth. Between 1972 and 1982 (the second climatic period), there was a global decline in sea temperatures and a rise in salinity. In the final period, temperatures were high and salinity was low and variable.

\section{MATERIALS AND METHODS}

Trawl surveys. Between 1956 and 1992, a number of bottom trawl surveys of the demersal fishery resources on the continental shelf and upper slope off Ghana were conducted (Koranteng 1998). The Guinean Trawling Survey (GTS), organised by the Scientific, Technical and Research Commission of the Organisation of African Unity (OAU/STRC) in 1963/4 (Williams 1968), was the first survey that covered the entire continental shelf of Ghana. From 1969 the Marine Fisheries Research Division (MFRD) of Ghana also conducted a number of bottom trawl surveys in Ghana's marine waters.

The data sets from the GTS (1963/4) and MFRD surveys of 1981/2 (MFRD3) and 1989 (MFRD5) are used in this study. The GTS was conducted during the first climatic period described above, MFRD3 and MFRD5

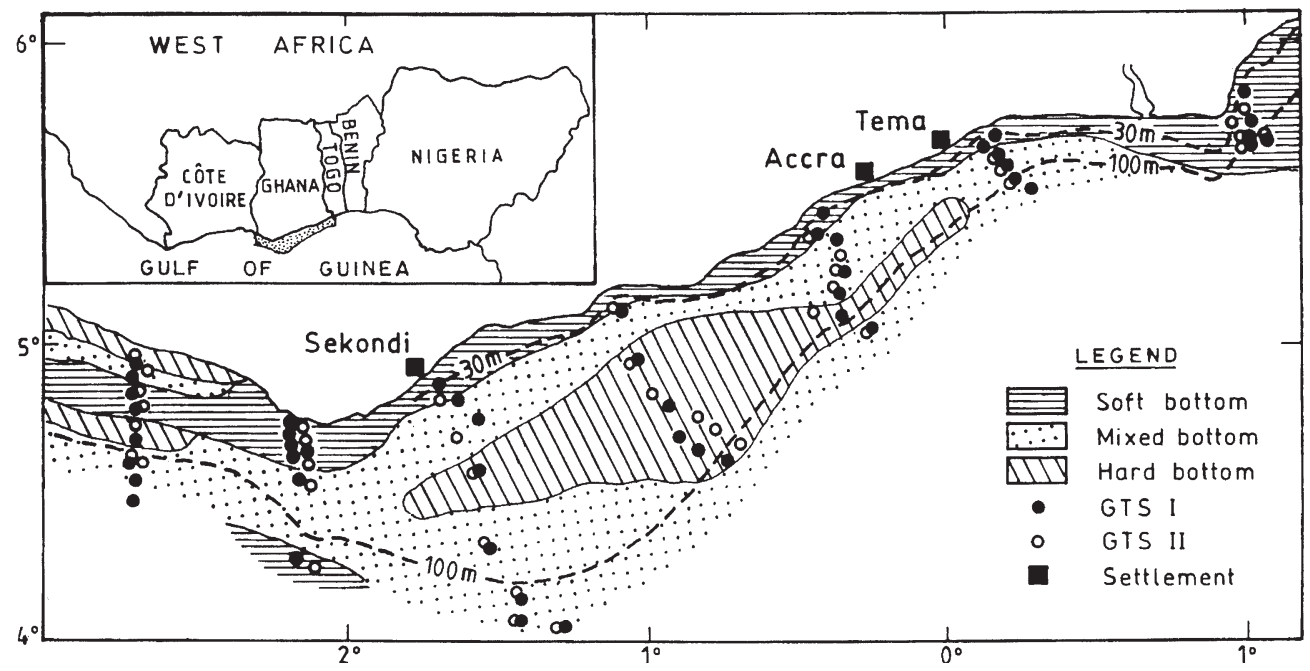

Fig. 1. The Gulf of Guinea, West Africa (inset), showing area surveyed off Ghana. Enlargement shows distribution of bottom sediments and location of hauls in Guinean Trawling Survey (GTS) 
were conducted during the second and third climatic periods respectively. The 2 MFRD surveys were similar in terms of spatial and temporal coverage and in survey methods. The GTS was the only survey of similar spatial coverage conducted in Ghanaian waters during the first climatic period.

GTS was in 2 phases; GUINEAN I and GUINEAN II. Off the coast of Ghana, GUINEAN I was in September 1963 and GUINEAN II was in March 1964. Two identical vessels each measuring $35 \mathrm{~m}$ long and having a gross registered tonnage of 200 were used. A trawling speed of $6.5 \mathrm{~km} \mathrm{~h}^{-1}$ was maintained and the survey net had a wing spread (distance between the tips of the net during trawling) of $16.4 \mathrm{~m}$ and codend mesh size of $40 \mathrm{~mm}$. Trawl hauls were taken according to a systematic sampling design that covered 7 transects (each laid perpendicular to the coastline) that were placed about $64 \mathrm{~km}$ apart. There were 8 sampling stations on each transect located at $15-20,30,40,50,70-75,100$, 200 and $400-600 \mathrm{~m}$ depth.

On reaching the sampling station the net was shot at the pre-determined depth and a trawling time of $1 \mathrm{~h}$ was maintained. After hauling in the net, the catch was sorted according to species. In some cases the specimen could only be identified to genus level. The total weight and number of each species in the catch were obtained by direct weighing and counting or estimated from sub-samples when the catch was large.

In the MFRD surveys, a stratified semi-random sampling design was used. In this design, the shelf was divided into 3 zones, 9 strata and 10 sectors, resulting in 40 trawl stations (Koranteng 1984). The depth range was between 10 and $75 \mathrm{~m}$. The survey area forms about $78 \%$ of the total shelf area of Ghana (Williams 1968). A few hauls were taken in the 75 to $100 \mathrm{~m}$ depth zone. In the MFRD surveys, all stations were sampled during the upwelling periods (Jan, Jul/Aug) and also during the stratified periods (Apr/May, Oct/Nov). The sampling procedures were as those used in the GTS survey except that within the confines of a station, the depth and trawling direction were chosen at random and the duration of tow was $30 \mathrm{~min}$. The catch was sorted and identified according to keys provided by Blache et al. (1970) and Fischer et al. (1981). The weight and number of each species were determined as described above for the GTS survey. The same vessel $(29 \mathrm{~m}$ multipurpose research vessel, trawling speed $5.6 \mathrm{~km} \mathrm{~h}^{-1}$ ) was used. The survey net also had a codend mesh of $40 \mathrm{~mm}$ and a wing spread of $16.4 \mathrm{~m}$.

Trawl data. 91 hauls from the GTS (64 in waters shallower than $75 \mathrm{~m}$ ), 70 hauls from MFRD3, and 72 hauls from MFRD5 were included in the analyses. All catch data were input to the NAN-SIS computer program for trawl survey data logging and analysis (Stromme 1992); these were extrapolated to catch-per-hour traw- ling. All fish names were cross-checked with entries in FISHBASE (FishBase 1998).

Environmental data. At the beginning or end of every haul, water temperature was obtained from thermometers mounted on Nansen reversing bottles, which were also used to collect water samples for analysis in the laboratory. Salinity and dissolved oxygen were determined from the water samples using a salinometer and Winkler titration method respectively. In the MFRD surveys, sea surface temperature was also recorded with a continuous temperature recorder mounted on the survey vessel.

The hydrographic variables used in the analysis are water temperature, salinity, and dissolved oxygen measured at depths trawled. Other environmental variables are the depth sampled and type of bottom sediment at the stations trawled. Bottom type information was obtained from sediment maps produced during GTS and also from Ramos et al. (1990). These were classified as follows: Hard (predominantly sand, shell, rock, gravel, grit or coral); Soft (predominantly mud); and, Mixed (combination of hard and soft).

Data analysis. A Two-way Indicator Analysis (TWIA) method implemented by TWINSPAN (Hill 1979) was used to obtain the species groupings in the trawl survey data. In the TWIA method, a classification of the samples is first constructed. This is then used to obtain a classification of the species according to their ecological preferences. The 2 classifications are then used together to obtain an ordered 2-way table that expresses the species' synecological relations as succinctly as possible (Hill 1979). Stations and species are then arranged along the major gradients in the data. The number of sub-divisions of the data is determined inter alia by the length of the gradient, the size of the eigenvalues obtained from the ordination and presence of suitable indicator species which are representative of the groups.

TWINSPAN uses a divisive cluster analysis algorithm to classify the samples and correspondence analysis (CA) to perform the ordination. The importance values (weights) are converted to a scale based on lower class limits before being used in the analysis. For this work, the class limits were 0, 0.5, 5, 50 and $500 \mathrm{~kg}$.

A further ordination of the data was performed using Detrended Correspondence Analysis (DCA, Hill \& Gauch 1980). DCA is a modification of the method of correspondence analysis (CA) and is intended to remove the 2 defects of CA, namely the 'arch effect' and compression of the ends of the first ordination axis (Gauch 1994). The DCA routine contained in CANOCO (ter Braak 1991), a community ecology computer program, was used in this work. Weights of the catches were used for the analysis (Bianchi \& Hoisæter 1992). 


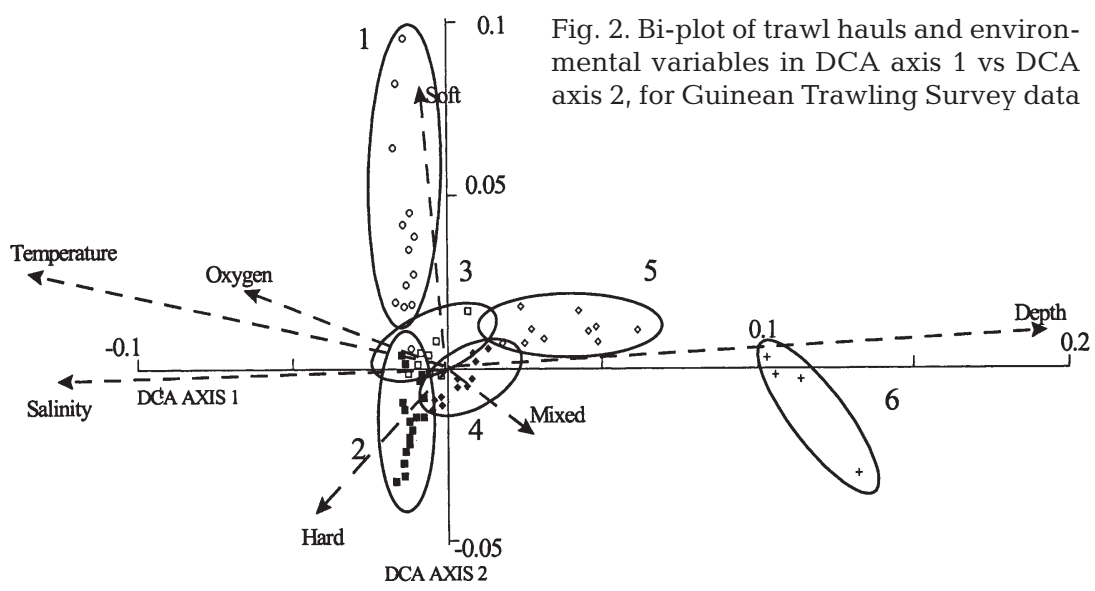

depth sampled and type of sediment. The 3 bottom types were treated as 3 levels of 1 nominal variable (bottom type). The CANOCO program package also correlates the ordination axes with the environmental variables. The significance of each correlation was assessed with a Student's $t$-statistic.

The GTS cruises were analysed first. Using the results of TWINSPAN to label the sites/hauls, the DCA scores (from CANOCO) were plotted using the drawing tools available in the CANODRAW computer program (Smilauer 1992). The MFRD3 and Each weight $(x)$ was converted to $\log (x+1)$ in order to stabilize the variance, as a Gaussian relationship between species abundance and each environmental variable was assumed. The environmental variables included in the analysis were bottom temperature, salinity, and dissolved oxygen. Also included were
MFRD5 data were similarly analysed. For the results to be comparable, the GTS data were re-analysed using only hauls made between 10 and $75 \mathrm{~m}$ depth.

The most important species in each assemblage were obtained using an index of relative importance (IRI) defined as:

Table 1. Community environmental parameters, mean (SD), and indicator species

\begin{tabular}{|c|c|c|c|c|}
\hline Survey & Variable & Group 1 & Group 2 & Group 3 \\
\hline \multirow[t]{14}{*}{ GTS } & No. of stations & 16 & 25 & 9 \\
\hline & Hard & & 0.4 & \\
\hline & Mixed & 0.4 & 0.6 & 0.4 \\
\hline & Soft & 0.6 & & 0.6 \\
\hline & Depth (m) & $28(8)$ & $37(10)$ & $49(10)$ \\
\hline & Temperature $\left({ }^{\circ} \mathrm{C}\right)$ & $20.8(1.0)$ & $19.8(1.3)$ & $19.4(1.2)$ \\
\hline & Salinity $(\% \circ)$ & $35.85(0.09)$ & $35.82(0.12)$ & $35.88(0.09)$ \\
\hline & Oxygen $\left(\mathrm{ml} \mathrm{l}^{-1}\right)$ & $3.13(0.74)$ & $2.98(0.62)$ & $2.44(0.70)$ \\
\hline & \multirow[t]{2}{*}{ Indicator species } & \multirow{2}{*}{$\begin{array}{l}\text { Serlene dorsalis } \\
\text { Galeoides decadactylus } \\
\text { Acanthostracion guineensis }\end{array}$} & Balistes forcipatus & Penaeus notialis \\
\hline & & & Aluterus punctatus & Brachydeuterus auritus \\
\hline & \multirow[t]{4}{*}{ Other important species } & \multirow{3}{*}{$\begin{array}{l}\text { Brachydeuterus auritus } \\
\text { Ilisha africana } \\
\text { Pseudotolithus senegalensis }\end{array}$} & Pagellus bellottii & Pagellus bellottii \\
\hline & & & Brachydeuterus auritus & IS Trachurus spp. \\
\hline & & & s ridirur us spp. & Raja miraletus \\
\hline & & Group 4 & Group 5 & Group 6 \\
\hline \multirow[t]{14}{*}{ GTS } & No. of stations & 26 & 11 & 4 \\
\hline & Hard & 0.3 & & \\
\hline & Mixed & 0.6 & 0.7 & 0.8 \\
\hline & Soft & 0.1 & 0.3 & 0.2 \\
\hline & Depth (m) & $87(32)$ & 217 (43) & $411(23)$ \\
\hline & Temperature $\left({ }^{\circ} \mathrm{C}\right)$ & $17.5(1.3)$ & $14.0(1.4)$ & $11.0(3.0)$ \\
\hline & Salinity (\%o) & $35.74(0.09)$ & $35.41(0.15)$ & $35.37(0.46)$ \\
\hline & Oxygen $\left(\mathrm{ml} \mathrm{l}^{-1}\right)$ & $2.74(0.54)$ & $2.23(0.54)$ & $2.07(0.65)$ \\
\hline & \multirow[t]{3}{*}{ Indicator species } & Dentex congoensis & & Hymenocephalus italicus \\
\hline & & Boops boops & & \\
\hline & & Squatina oculata & & \\
\hline & \multirow[t]{3}{*}{ Other important species } & Trachurus spp. & Paracubiceps ledanoisi $S$ & Squalus fernandus \\
\hline & & Scomber japonicus & rachurus spp. & Centrophorus uyato \\
\hline & & Ilisha africana & oligo sp. & Hypoclydonia bella \\
\hline
\end{tabular}


Table 2. Pearson's product-moment correlation coefficient $r$ of species axes 1-4 with bottom environmental variables

\begin{tabular}{|c|c|c|c|c|c|c|c|}
\hline Survey & Variable & $\begin{array}{l}\text { Species } \\
\text { Axis } 1\end{array}$ & $\begin{array}{l}\text { Species } \\
\text { Axis } 2\end{array}$ & Survey & Variable & $\begin{array}{c}\text { Species } \\
\text { Axis } 1\end{array}$ & $\begin{array}{c}\text { Species } \\
\text { Axis } 2\end{array}$ \\
\hline \multirow{8}{*}{$\begin{array}{l}\text { GTS } \\
\text { (all hauls) }\end{array}$} & Hard & -0.13 & $-0.29^{* *}$ & \multirow[t]{8}{*}{ MFRD3 } & Hard & $-0.49^{* * *}$ & 0.09 \\
\hline & Mixed & 0.13 & -0.14 & & Mixed & $0.30^{* *}$ & 0.01 \\
\hline & Soft & -0.02 & $0.43^{* *}$ & & Soft & $0.30^{* *}$ & 0.13 \\
\hline & Depth & $0.95^{* *}$ & 0.01 & & Depth & $-0.29^{* *}$ & $0.79^{* * *}$ \\
\hline & Temperature & $-0.81^{* *}$ & 0.10 & & Temperature & $0.23^{*}$ & $-0.65^{* * *}$ \\
\hline & Salinity & $-0.64^{* *}$ & -0.01 & & Salinity & -0.02 & 0.28 \\
\hline & Oxygen & $-0.34^{* *}$ & 0.11 & & Oxygen & 0.13 & $-0.54^{* * *}$ \\
\hline & Eigenvalues & 0.68 & 0.50 & & Eigenvalues & 0.40 & 0.34 \\
\hline \multirow{8}{*}{$\begin{array}{l}\text { GTS } \\
\text { (hauls at } \\
\leq 75 \mathrm{~m} \text { ) }\end{array}$} & Hard & $-0.31^{* *}$ & -0.02 & \multirow[t]{8}{*}{ MFRD5 } & Hard & $-0.29^{* *}$ & $-0.30^{* *}$ \\
\hline & Mixed & -0.11 & $-0.29^{*}$ & & Mixed & 0.16 & 0.12 \\
\hline & Soft & $0.44^{* *}$ & $0.37^{* *}$ & & Soft & $0.20^{*}$ & $0.26^{* *}$ \\
\hline & Depth & $-0.51^{* * *}$ & $-0.71^{* * *}$ & & Depth & $-0.42^{* * *}$ & $0.60^{* * *}$ \\
\hline & Temperature & $0.47^{* * *}$ & $-0.47^{* * *}$ & & Temperature & 0.18 & $-0.54^{* * *}$ \\
\hline & Salinity & $0.18^{*}$ & -0.07 & & Salinity & 0.08 & -0.07 \\
\hline & Oxygen & $0.21^{*}$ & -0.19 & & Oxygen & -0.02 & $-0.47^{* * *}$ \\
\hline & Eigenvalues & 0.54 & 0.40 & & Eigenvalues & 0.46 & 0.36 \\
\hline r significa & $\left.{ }^{*}\right) \mathrm{p}<0.05$ & $0.01 ; i^{*}$ & 0.001 & & & & \\
\hline
\end{tabular}

$$
\mathrm{IRI}=\% \mathrm{~W} \times \% \mathrm{~F}
$$

where $\% \mathrm{~W}$ is the percentage contribution by weight of each species in the assemblage and \%F is the percentage of the number of times that the species occurred in hauls from the assemblage. This index was modified from that of Pinkas et al. (1971). Species with IRI values $\geq 50$ in each assemblage were included in a short list of the most important species of the assemblage.

Seasonal (upwelling, stratified) and long-term changes in the assemblages were investigated. For each survey and assemblage, a list of the most important species for the upwelling and stratified seasons was compiled. Thus the species that were present mainly during the upwelling period, those present in the stratified period and those that were regularly present in the assemblage ('residents') were determined.

Similarities in the composition of the various assemblages were assessed using the 'Jaccard Index' $S j$ (Southwood 1988) and the 'Similarity Ratio' Sr (van Tongeren 1995). For 2 sampled sites (1 and 2), $S j$ is calculated as:

$$
S j=\frac{C}{A+B-C}
$$

where $C$ is the number of species common to both sites, and $A$ and $B$ are the total number of species at the first and second sites respectively. To be adapted for use in this work, all stations in each assemblage were grouped and the assemblage treated as a 'site'. Following the notation of van Tongeren (1995), the Similarity Ratio for the comparison of 2 sites ( $i$ and $j$ ) is calculated from:

$$
S r_{\mathrm{ij}}=\frac{\sum_{k} y_{k \mathrm{i}} y_{k \mathrm{j}}}{\sum_{k} y_{k i}{ }^{2}+\sum_{k} y_{k \mathrm{j}}{ }^{2}-\sum_{k} y_{k i} y_{k j}}
$$

where $y_{k i}$ is the abundance of the $k^{\text {th }}$ species at site $i$, $y_{k j}$ is its abundance at site $\mathrm{j}$, and $y_{k i} y_{k j}$ is the product of the abundance of the $k^{\text {th }}$ species occurring at both sites. $S r$ is basically a quantitative equivalent of $S j$ (van Tongeren 1995).

\section{RESULTS}

Six groups of stations were identified from the GTS data; salient properties of the 6 groups are presented in Table 1. The table gives the number of trawl stations that make up the group, average values of each environmental parameter, the indicator species and some of the other important species of each assemblage. Each level of the nominal variable (bottom type) was scaled from 0 to 1 , where 0 denotes non-existence and 1 is a predominance of the type of bottom. Table 2 gives the Pearson's product-moment correlation coefficient of the first 2 axes with temperature, salinity, dissolved oxygen, depth and bottom type. The significance of each correlation is indicated. The table also gives corresponding information for the subset of GTS data and the 2 MFRD surveys.

An example of the CANODRAW bi-plots of sites and environmental parameters in the DCA axis 1 against DCA axis 2 plane for the complete GTS data is given in Fig. 2. Hauls in the same group (i.e. assemblage) are indicated by the same symbol and enclosed in an ellipse. To be able to compare the plots for the various 
Table 3. Total weight $(\mathrm{W}, \mathrm{kg})$, percentage weight $(\% \mathrm{~W})$, and frequency of occurrence $(\mathrm{F}$, no. of stations) of main species in each group of stations; Guinean Trawling Survey, 1963-64

\begin{tabular}{|c|c|c|c|c|c|c|c|}
\hline Species & $\begin{array}{c}\mathrm{W} \\
(\mathrm{kg})\end{array}$ & $\begin{array}{l}\% \\
\mathrm{~W}\end{array}$ & $\mathrm{~F}$ & Species & $\begin{array}{c}\mathrm{W} \\
(\mathrm{kg})\end{array}$ & $\begin{array}{l}\% \\
\mathrm{~W}\end{array}$ & $\mathrm{~F}$ \\
\hline Group 1 (16 stations) & & & & Group 4 (26 stations) & & & \\
\hline Brachydeuterus auritus & 2616 & 34.2 & 15 & Trachurus sp. & 3145 & 18.7 & 24 \\
\hline Serlene sorsalis & 544 & 7.1 & 13 & Dentex congoensis & 2237 & 13.3 & 24 \\
\hline Galeoides decadactylus & 565 & 7.4 & 11 & Scomber japonicus & 2263 & 13.5 & 22 \\
\hline Pseudotolithus senegalensis & $S \quad 586$ & 7.7 & 10 & Priacanthus arenatus & 1210 & 7.2 & 24 \\
\hline Ilisha africana & 620 & 8.1 & 7 & Pagelus bellottii & 1179 & 7.0 & 21 \\
\hline Sparus caeruleostictus & 313 & 4.1 & 9 & Dentex angolensis & 820 & 4.9 & 22 \\
\hline Pagellus bellottii & 235 & 3.1 & 10 & Sardinella aurita & 1370 & 8.2 & 10 \\
\hline Drepane africana & 221 & 2.9 & 9 & Boops boops & 529 & 3.1 & 21 \\
\hline Raja miraletus & 149 & 2.0 & 12 & Epinephelus aeneus & 550 & 3.3 & 19 \\
\hline Trichiurus lepturus & 152 & 2.0 & 10 & Paracubiceps ledanoisi & 601 & 3.6 & 15 \\
\hline Loligo sp. & 250 & 3.3 & 6 & Dentex gibbosus & 179 & 1.1 & 19 \\
\hline Pomadasys jubelini & 100 & 1.3 & 8 & Total & 14084 & 83.8 & \\
\hline Pteroscion peli & 132 & 1.7 & 6 & Total (all stations) & 16812 & & \\
\hline Epenephelus aeneus & 88 & 1.2 & 8 & & & & \\
\hline Total & 6571 & 85.9 & & & & & \\
\hline Total (all species) & 7646 & & & & & & \\
\hline Group 2 (25 stations) & & & & Group 5 (11 stations) & & & \\
\hline Pagelus bellottii & 1926 & 16.5 & 25 & Paracubiceps ledanoisi & 1567 & 26.4 & 10 \\
\hline Brachydeuterus auritus & 1394 & 12.0 & 17 & Trachurus spp. & 1188 & 20.0 & 4 \\
\hline Trachurus spp. & 1008 & 8.6 & 18 & Antigonia capros & 431 & 7.3 & 8 \\
\hline Sparus caeruleostictus & 746 & 6.4 & 24 & Loligo sp. & 435 & 7.3 & 7 \\
\hline Pseudupeneus prayensis & 585 & 5.0 & 23 & Pentheroscion mbizi & 333 & 5.6 & 7 \\
\hline Priacanthus arenatus & 420 & 3.6 & 24 & Smaris macrolepidotus & 327 & 5.5 & 7 \\
\hline Dentex canariensis & 352 & 3.0 & 20 & Chlorophthalmus atlanticus & IS 119 & 2.0 & 7 \\
\hline Sardinella aurita & 432 & 3.7 & 16 & Paragaleus pectoralis & 265 & 4.5 & 3 \\
\hline Epinephelus aeneus & 339 & 2.9 & 19 & Paracubiceps multisquamis & $S \quad 98$ & 1.7 & 5 \\
\hline Scomber japonicus & 364 & 3.1 & 16 & Priacanthus arenatus & 88 & 1.5 & 5 \\
\hline Dactylopterus volitans & 224 & 1.9 & 23 & Dentex angolensis & 101 & 1.7 & 4 \\
\hline Decapterus sp. & 381 & 3.3 & 11 & Dentex congoensis & 66 & 1.1 & 5 \\
\hline Loligo sp. & 196 & 1.7 & 20 & Total & 5019 & 84.6 & \\
\hline Lutjanus agennes & 207 & 1.8 & 17 & Total (all stations) & 5933 & & \\
\hline Lutjanus fulgens & 184 & 1.6 & 18 & & & & \\
\hline Balistes forcipatus & 153 & 1.3 & 21 & & & & \\
\hline Sphyraena sp. & 230 & 2.0 & 14 & & & & \\
\hline Acanthurus monroviae & 162 & 1.4 & 18 & & & & \\
\hline Lethrinus atlanticus & 98 & 0.8 & 18 & & & & \\
\hline Raja miraletus & 66 & 0.6 & 23 & & & & \\
\hline Total & 9467 & 81.2 & & & & & \\
\hline Total (all species) & 11657 & & & & & & \\
\hline Group 3 (9 stations) & & & & Group 6 (4 stations) & & & \\
\hline Sparus caeruleostictus & 569 & 17.0 & 9 & Squalus fernandus & 501 & 47.5 & 2 \\
\hline Brachydeuterus auritus & 771 & 23.1 & 6 & Hypoclydonia bella & 116 & 11.0 & 2 \\
\hline Trachurus spp. & 444 & 13.3 & 7 & Centrophorus uyato & 134 & 12.7 & 1 \\
\hline Raja miraletus & 155 & 4.6 & 7 & Paracubiceps multisquamis & 44 & 4.2 & 3 \\
\hline Priacanthus arenatus & 124 & 3.7 & 7 & Chlorophthalmus sp. & 41 & 3.9 & 2 \\
\hline Epinephelus aeneus & 81 & 2.4 & 6 & Chlorophthalmus atlanticus & IS 71 & 6.7 & 1 \\
\hline Pseudupeneus prayensis & 88 & 2.6 & 5 & Carcharhinus signatus & 31 & 2.9 & 2 \\
\hline Sparus caeruleostictus & 62 & 1.9 & 5 & Paracubiceps ledanoisi & 32 & 3.0 & 1 \\
\hline Lepidotrigla cadmani & 59 & 1.8 & 4 & Total & 970 & 92.0 & \\
\hline Loligo sp. & 32 & 0.9 & 6 & Total (all species) & 1055 & & \\
\hline Dentex congoensis & 58 & 1.7 & 3 & & & & \\
\hline Cynoglossus canariensis & 34 & 1.0 & 5 & & & & \\
\hline Penaeus notialis & 22 & 0.7 & 7 & & & & \\
\hline Sardinella aurita & 39 & 1.2 & 4 & & & & \\
\hline Dentex angolensis & 38 & 1.1 & 4 & & & & \\
\hline Total & 2576 & 77.1 & & & & & \\
\hline Total (all species) & 3343 & & & & & & \\
\hline
\end{tabular}


surveys, the axes are scaled between -1 and 1 . The biplot gives an indication of the environmental parameters that separate the groups, and characteristics of each group are also indicated in Table 2. For example, Group 1 is a shallow water assemblage on soft bottom, Group 2 is also in shallow waters but on hard bottom, Groups 3 and 4 (at mid depths) are separated mainly by bottom type ( 3 towards soft and 4 towards mixed bottom) and Groups 5 and 6 are separated from the others mainly by depth. A dendrogram showing the order of grouping and relationships between the 6 GTS groups is given in Fig. 3.

The list of species with IRI value $\geq 50$ in each of the 6 groups identified from the GTS data is given in Table 3. In this table, $\mathrm{W}$ is total weight caught in the survey, $\% \mathrm{~W}$ is percentage of total weight contributed by a particular species and $\mathrm{F}$ is the number of hauls in which the species was caught throughout the survey. The species listed form 77 to $92 \%$ of the total catch in each group. As species were not placed exclusively in one group or the other, a number of species occur in $>1$ group. The occurrence of the bigeye grunt Brachydeuterus auritus and the sparid Sparus caeruleostictus in all 3 groups in shallow water is noticeable. Groups 5 and 6 share only a few species with the other groups.

Table 4 gives the list of the most important species found in each of the 2 main seasons (upwelling, stratified). With the GTS data, only hauls in depth $<75 \mathrm{~m}$ were included in this analysis. In the tables, the names in bold are for species found in both seasons ('resident' species). The species above these are present mainly during the upwelling period and those below are present mainly during the stratified period. In the third group, Brachydeuterus auritus was always found only during the stratified period. This is one of the species described by Longhurst (1969) as eurybathic.

Calculated values of the Jaccard Index and Similarity Ratio are presented in Tables $5 \& 6$ respectively. These were computed for both upwelling and stratified seasons. Figures above shaded diagonal are for the upwelling period, and those below are for the stratified period.

\section{DISCUSSION}

From the GTS data the 6 groups identified in this work correspond to the following assemblages (named by Longhurst 1969):

Group 1: Sciaenid; Group 2: Lutjanid; Group 3: Sparid (shallow part); Group 4: Sparid (deep part); Group 5: Deep shelf; Group 6: Upper slope.

The group of species referred to as eurybathic or thermocline species by Longhurst (1969) is not isolated

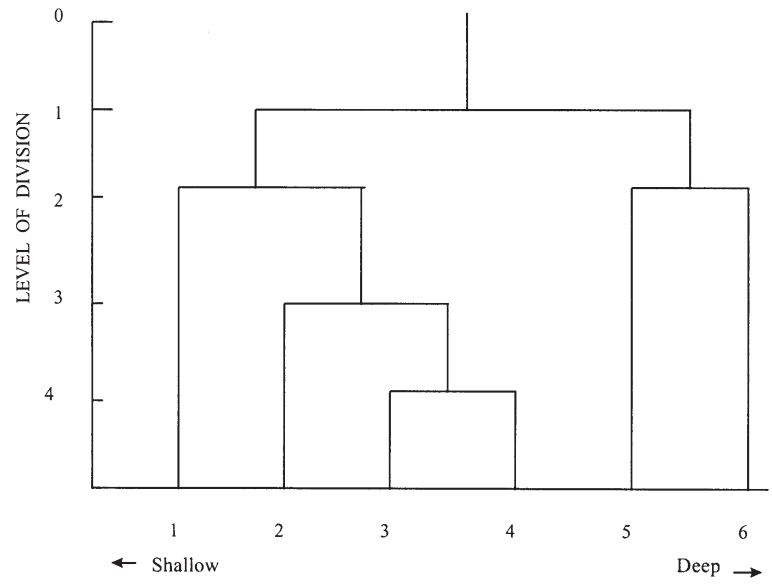

Fig. 3. Dendrogram showing clustering order of groups of stations for Guinean Trawling Survey data analysed with TWINSPAN

in this work; these are generally included in the second assemblage. Also, the estuarine sciaenid community described by Longhurst (1969) is not represented in these results considering the range of depths (especially the minimum depth) covered in the surveys used in this study.

The first pair of assemblages (sciaenid and lutjanid) is found in waters shallower than $40 \mathrm{~m}$ (Table 1). This is less than the average depth of the thermocline off Ghana, which is $\sim 41 \mathrm{~m}$ (Koranteng 1998). The second pair is in 40 to $100 \mathrm{~m}$ depth and the last pair in waters deeper than $100 \mathrm{~m}$. The 2 sparid communities (Groups 3 and 4) originate from within the thermocline depth and stretch seaward into deeper waters and the deep shelf and upper slope assemblages lie well below the thermocline layer.

For the GTS data (Table 2), the significantly high correlation between the first DCA axis and depth, bottom temperature, bottom salinity and bottom dissolved oxygen, and also between sediment type and the second axis, the importance of these variables in the determination of the structure of demersal species assemblages in the study area is shown. Depth appears to be the most important variable in the ordination, followed by bottom temperature, salinity and dissolved oxygen. These physico-chemical variables are themselves closely related to depth in the oceans and usually change by seasons. Thus the upwelling, which appears to change the properties of water masses, may also have an effect on the structure of demersal species assemblages.

Sediment type then follows in importance, being highly significant $(\mathrm{p}<0.01)$ on the second DCA axis (Table 2). This shows the importance of this feature, which, like depth, is invariant with time, at least within the time frame considered. 
Table 4. Seasonal membership of assemblages; species listed in bold are 'resident' species found in both seasons; those above were found in the upwelling season only; those below were found in the stratified season only

\begin{tabular}{|c|c|c|}
\hline Group 1 & Group 2 & Group 3 \\
\hline \multicolumn{3}{|c|}{ GTS (only stations of depth $75 \mathrm{~m}$ or less) } \\
\hline Drepane africana & Decapterus spp. & Dentex gibbosus \\
\hline Epenephelus aeneus & Fistularia villosa & Raja miraletus \\
\hline Ilisha africana & Lutjanus dentatus & Sardinella aurita \\
\hline Loligo sp. & Pomadasys incisus & Boops boops \\
\hline Pomadasys jubelini & Lutjanus dentatus & Scomber japonicus \\
\hline Pseudotolithus brachygnathus & Trachinocephalus myops & \\
\hline Pseudotolithus typus & Acanthurus monroviae & Sparus caeruleostictus \\
\hline \multirow[t]{2}{*}{ Sparus caeruleostictus } & Balistes forcipatus & Priacanthus arenatus \\
\hline & Loligo sp. & Epenephelus aeneus \\
\hline Brachydeuterus auritus & Lutjanus agennes & Pagellus bellottii \\
\hline Galeoides decadactilus & Lutjanus fulgens & Dentex congoensis \\
\hline Pagellus bellottii & Raja miraletus & Trachurus sp. \\
\hline Raja miraletus & Scomber japonicus & Pseudupeneus prayensis \\
\hline Trichiurus lepturus & Turtles & Dentex angolensis \\
\hline \multicolumn{3}{|l|}{ Pseudotolithus senegalensis } \\
\hline \multirow[t]{2}{*}{ Pteroscion peli } & Brachydeuterus auritus & Brachydeuterus auritus \\
\hline & Dactylopterus volitans & Sphyraena sp. \\
\hline \multirow[t]{8}{*}{ Sphyraena sp. } & Dentex canariensis & Pentheroscion mbizi \\
\hline & Epenephelus aeneus & Sardinella maderensis \\
\hline & Pagellus bellottii & \\
\hline & Priacanthus arenatus & \\
\hline & Pseudupeneus prayensis & \\
\hline & Sparus caeruleostictus & \\
\hline & Trachurus sp. & \\
\hline & Sardinella aurita & \\
\hline \multicolumn{3}{|l|}{ MFRD3 1981-82 } \\
\hline Decapterus rhonchus & Balistes capriscus & Acanthurus monroviae \\
\hline Pagellus bellottii & Boops boops & Boops boops \\
\hline Pomadasys incisus & Brachydeuterus auritus & Chaetodon luciae \\
\hline Priacanthus arenatus & Chromis lineatus & Dactylopterus volitans \\
\hline Pseudupeneus prayensis & Dentex angolensis & Distodon speciosus \\
\hline \multirow[t]{2}{*}{ Sepia sp. } & Dentex congoensis & Fistularia villosa \\
\hline & Dentex gibbosus & Lutjanus fulgens \\
\hline Balistes capriscus & Paracubiceps ledanoisi & Lutjanus goreensis \\
\hline Brachydeuterus auritus & Rhizoprionodon acutus & Rhizoprionodon acutus \\
\hline Chloroscombrus chrysurus & Trachurus sp. & Trigla sp. \\
\hline Dentex canariensis & Umbrina canariensis & \\
\hline Epenephelus aeneus & & Balistes capriscus \\
\hline Galeoides decadactylus & Dactylopterus volitans & Dentex canariensis \\
\hline Selene dorsalis & Dentex canariensis & Dentex gibbosus \\
\hline \multirow[t]{2}{*}{ Sparus caeruleostictus } & Epenephelus aeneus & Epenephelus aeneus \\
\hline & Fistularia villosa & Pagellus bellottii \\
\hline Elops senegalensis & Pagellus bellottii & Priacanthus arenatus \\
\hline Engraulis encrasicolus & Priacanthus arenatus & Pseudupeneus prayensis \\
\hline Ilisha africana & Pseudupeneus prayensis & Sepia sp. \\
\hline Pseudotolithus senegalensis & Sparus caeruleostictus & Sparus caeruleostictus \\
\hline Pseudotolithus sp. & Acanthostracion guineensis & \\
\hline Pteroscion peli & Acanthurus monroviae & Brachydeuterus auritus \\
\hline Scyacium micrurum & Balistes forcipatus & Chloroscombrus chrysurus \\
\hline \multirow[t]{8}{*}{ Sphyraena sphyraena } & Chaetodon sp. & Chromis lineatus \\
\hline & Chloroscombrus chrysurus & Decapterus rhonchus \\
\hline & Decapterus sp. & Lepidotrigla sp. \\
\hline & Lagocephalus laevigatus & Pomadasys incisus \\
\hline & Lethrinus atlanticus & Raja miraletus \\
\hline & Lutjanus fulgens & Sardinella aurita \\
\hline & Scyacium micrurum & Selene dorsalis \\
\hline & Sepia sp. & \\
\hline
\end{tabular}


Table 4 (continued)

\begin{tabular}{|c|c|c|}
\hline Group 1 & Group 2 & Group 3 \\
\hline \multicolumn{3}{|l|}{ MFRD5 1989} \\
\hline Lagocephalus laevigatus & Acanthurus monroviae & Anthias anthias \\
\hline Pagellus bellottii & Boops boops & Boops boops \\
\hline Pentheroscion mbizi & Decapterus rhonchus & Chromis sp. \\
\hline Pomadasys incisus & Pomadasys incisus & Decapterus sp. \\
\hline Priacanthus arenatus & Trachurus sp. & Dentex canariensis \\
\hline Pteroscion peli & Trachurus trecae & Dentex gibbosus \\
\hline Rhizoprionodon acutus & & Sardinella aurita \\
\hline Trachinocephalus myops & Balistes forcipatus & Scomber japonicus \\
\hline \multirow[t]{2}{*}{ Trachurus trecae } & Brachydeuterus auritus & \\
\hline & Chloroscombrus chrysurus & Dactylopterus volitans \\
\hline Brachydeuterus auritus & Dentex canariensis & Dentex congoensis \\
\hline Galeoides decadactilus & Fistularia villosa & Epenephelus aeneus \\
\hline Penaeus notialis & Lagocephalus laevigatus & Fistularia villosa \\
\hline Pomadasys jubelini & Lutjanus fulgens & Pagellus bellottii \\
\hline Pseudupeneus prayensis & Pagellus bellottii & Pseudupeneus prayensis \\
\hline Sepia officinalis & Priacanthus arenatus & Rhizoprionodon acutus \\
\hline Selene dorsalis & Pseudupeneus prayensis & Sparus caeruleostictus \\
\hline \multirow{2}{*}{ Sparus caeruleostictus } & Sepia officinalis & Trichiurus lepturus \\
\hline & Sparus caeruleostictus & Balistes forcipatus \\
\hline Chilomycterus spinosus & & Brachydeuterus auritus \\
\hline Chloroscombrus chrysurus & Apsilus fuscus & Chloroscombrus chrysurus \\
\hline Dasyatis sp. & Balistes capriscus & Lagocephalus laevigatus \\
\hline Dentex canariensis & Chaetodon sp. & Lepidotrigla sp. \\
\hline Drepane africana & Chromis lineatus & Priacanthus arenatus \\
\hline Elops senegalensis & Dactylopterus volitans & Raja miraletus \\
\hline Epenephelus aeneus & Decapterus sp. & Scyacium micrurum \\
\hline Eucinostomus melanopterus & Epinephelus aeneus & Sepia officinalis \\
\hline Grammoplites gruveli & Lethrinus atlanticus & Selene dorsalis \\
\hline Lutjanus fulgens & Sphyraena sphyraena & Serranus accraensis \\
\hline Sardinella maderensis & Trigla sp. & Sphyraena sphyraena \\
\hline Sphyraena sphyraena & & Trachurus sp. \\
\hline Torpedo sp. & & Umbrina sp. \\
\hline
\end{tabular}

In the MFRD surveys, sediment type appears to be the most important factor determining assemblage structure. All levels of this variable are highly significant on the first DCA axis (Table 2). The second axis is dominated by depth and then temperature, dissolved oxygen and salinity. These results are rather different from the GTS results, which seems to imply that with a wide depth range, as was the case in the GTS, sediment type becomes secondary to depth as the principal factor influencing assemblage structure. From these data sets, it appears that when the depth range is not wide, then the most important factor affecting community structure is the type of sediment on the seabed, relegating depth to a secondary position. This appears to be a fractal problem whereby, on some gradients, the grain size could be an important factor in assemblage formation (e.g. Mahon et al. 1984).

From the plot of DCA axis 1 versus DCA axis 2 (Fig. 2), it appears that the first 2 species assemblages derived from the GTS data are separated mainly by sediment type - the first on soft bottom and the sec-
Table 5. Jaccard's index of similarity between pairs of assemblages for the same survey. Italics: upwelling period; bold: stratified period

\begin{tabular}{|c|c|c|c|c|c|c|c|c|c|}
\hline \multirow{2}{*}{ 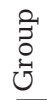 } & \multicolumn{3}{|c|}{ GTS } & \multicolumn{3}{|c|}{ MFRD3 } & \multicolumn{3}{|c|}{ MFRD5 } \\
\hline & 1 & 2 & 3 & 1 & 2 & 3 & 1 & 2 & 3 \\
\hline 1 & 1 & 0.27 & 0.35 & 1 & 0.45 & 0.37 & 1 & 0.43 & 0.33 \\
\hline 2 & 0.45 & 1 & 0.35 & 0.36 & 1 & 0.35 & 0.45 & 1 & 0.37 \\
\hline 3 & 0.40 & 0.41 & 1 & 0.36 & 0.46 & 1 & 0.39 & 0.46 & 1 \\
\hline
\end{tabular}

Table 6. Within-survey Similarity Ratios among the 3 assemblages. Italics: upwelling period; bold: stratified period

\begin{tabular}{|c|c|c|c|c|c|c|c|c|c|}
\hline \multirow{2}{*}{ 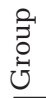 } & \multicolumn{3}{|c|}{ GTS } & \multicolumn{3}{|c|}{ MFRD3 } & \multicolumn{3}{|c|}{ MFRD5 } \\
\hline & 1 & 2 & 3 & 1 & 2 & 3 & 1 & 2 & 3 \\
\hline 1 & 1 & 0.09 & 0.01 & 1 & 0.17 & 0.10 & 1 & 0.20 & 0.06 \\
\hline 2 & 0.18 & 1 & 0.23 & 0.16 & 1 & 0.10 & 0.60 & 1 & 0.12 \\
\hline 3 & 0.01 & 0.28 & 1 & 0.30 & 0.07 & 1 & 0.01 & 0.04 & 1 \\
\hline
\end{tabular}


ond on hard bottom. Assemblages 3 and 4 are separated by both sediment type and depth. The last 2 assemblages are separated from the others mainly by depth. Consequently, it may be sufficient to regard depth and bottom sediment type as the principal forcing factors determining the structure of fish assemblages on the continental shelf and upper slope off Ghana. As temperature and dissolved oxygen also then become important on the second axis in the case of short depth range, it appears, therefore, that these physico-chemical parameters are important in the dynamics of the assemblages.

The information on the site-environmental variables bi-plots (Fig. 2) correspond with the habitat preferences of various species in the assemblages as described by Longhurst (1969), Williams (1968), Blache et al. (1970) and Schneider (1990).

The results obtained in this study, in one way or the other, corroborate those of similar studies undertaken elsewhere. For example, it has been shown by several authors (including Fager \& Longhurst 1968, Mahon et al. 1984, Yáñez-Arancibia et al. 1985, Bianchi 1992) that depth is the most important gradient along which faunal changes occur. Working on the entire GTS data collected from Guinea Bissau to Congo, Fager \& Longhurst (1968) attributed assemblage boundaries in the Gulf of Guinea to thermal discontinuity and sediment type, the latter of which also changes with depth.

The analyses carried out in this work on temporal and spatial patterns of community structure using the first 3 assemblages and the 3 surveys, only shows subtle seasonal and temporal differences in assemblage structure. The calculated values of the Jaccard Index and Similarity Ratio (Tables 5 \& 6) indicate that closest resemblance was found for assemblages 2 and 3 during the upwelling season and assemblages 1 and 2 in the stratified season. The first situation could be due to fishes in assemblage 3 moving closer inshore during the upwelling and the second perhaps due to assemblage 1 fishes moving away from shallow areas during the warm season (Koranteng 1998). It could also be due to seasonal inshore-offshore movement of fishes in assemblage 2 .

In general, the properties of the derived assemblages in the MFRD surveys are quite similar to each other and different from the GTS. This is true in both the upwelling and stratified periods. Differences in assemblage structure have been attributed to a differential response to changes in environmental forcing factors (Gulland \& Garcia 1984, Overholtz \& Tyler 1985, Macpherson \& Gordoa 1992). Thus, the differences may be as a consequence of the environmental perturbations observed during the climatic periods. For example, Gulland \& Garcia (1984) noted that the Sparid assemblage has affinity for the low temperature, high salinity environment that prevailed in the Gulf of Guinea during the second climatic period (1972 to 1982).

Differences in the assemblages during the period in question could also be a consequence of the proliferation of triggerfish Balistes capriscus, a species of the Sparid assemblage, and associated ecological changes in the Gulf of Guinea between 1972 and 1988 (AnsaEmmim 1979, Koranteng 1998). Koranteng (1998) showed that the increased abundance of triggerfish also destabilised the shallow water assemblages, especially the Lutjanid and the shallow part of the Sparid.

Changes in the pattern and intensity of fishing could well induce changes in the structure of demersal assemblages (Brown et al. 1976, Overholtz \& Tyler 1985). GTS was conducted 17 yr before MFRD3 and at a time when commercial trawling on the continental shelf of Ghana and neighbouring countries was much less intense than was the case at the time of the MFRD surveys. For example, the number of days fished by large industrial trawlers in Ghana's waters increased from 500 d in 1974 to 5500 d in 1990 (Koranteng 1998). This increase in fishing effort was partly due to the deployment of Ghanaian-registered vessels in home waters, as several countries declared $200 \mathrm{n}$ mile of exclusive economic zone in accordance with the Third United Nations Convention on the Law of the Sea.

It appears that natural and anthropogenic factors, conjointly or singly, affected the nature of species assemblages in Ghana's coastal waters. It is acknowledged, however, that it is often difficult, if not impossible, to separate natural fluctuations from those caused by anthropogenic factors such as exploitation (Cushing 1980, Sissenwine et al. 1982).

\section{CONCLUSION}

The analyses of community structure identified 6 species assemblages on the continental shelf and upper slope off Ghana. The first 2, namely the Sciaenid and Lutjanid assemblages, are predominantly suprathermocline whilst the 2 Sparid assemblages begin at the thermocline depth $(\sim 40 \mathrm{~m})$ and extend offshore. The last 2 (deep shelf and upper slope) assemblages occur well below the thermocline.

The Sciaenid community is associated with the soft, muddy substrate found in shallow waters generally $<40 \mathrm{~m}$ deep, and is made up mainly of species of the Pseudotolithus and Galeoides genera. Lying beyond this belt is a wide area of mixed-to-hard bottom, with which the Lutjanid and the Sparid assemblages (shallow and deep parts) are associated. There are clear faunal discontinuities around 30-40, 100 and $200 \mathrm{~m}$ depth. The first ecotone is closely related to bottom depth and the presence and depth of the thermocline, 
the second to a steep shelf drop, and the third to significant division between shelf and slope assemblages.

The structure of the assemblages is determined primarily by depth and sediment type, the latter being more important when considering a restricted depth gradient, as in the MFRD surveys. The dynamics of the assemblages, including seasonal movements of component species, are influenced by physico-chemical properties of the water masses (mainly temperature, salinity and dissolved oxygen). Therefore, the seasonal coastal upwelling that occurs in the western Gulf of Guinea and which changes the characteristics of the water masses on the continental shelf, would have an effect on the dynamics of the species assemblages.

The observed change in assemblage structure may also be due to increased industrial trawling and proliferation of triggerfish Balistes capriscus in Ghana's continental shelf waters. However, it is difficult from this study, to separate fluctuations due to long-term environmental changes from those caused by anthropogenic factors such as fishing.

Acknowledgements. I am grateful to Professor Jacqueline McGlade, Dr Gabriella Bianchi and the reviewers for their constructive criticism and comments that have undoubtedly improved this paper.

\section{LITERATURE CITED}

Ansa-Emmim M (1979) Occurrence of the triggerfish, Balistes capriscus (Gmel), on the continental shelf of Ghana. In: Report of the special working group on the evaluation of demersal stocks of the Ivory Coast-Zaire sector. CECAF/ECAF SERIES/79/14(En), FAO, Rome, p 20-27

Bianchi G (1992) Demersal Assemblages of tropical continental shelves. A study based on the data collected through the surveys of the RV 'Dr Fridtjof Nansen'. Dr Scient thesis, University of Bergen

Bianchi G, Hoisæter T (1992) The relative merits of using numbers and biomass in fish community studies. Mar Ecol Prog Ser 85:25-33

Binet D, Marchal E (1993) The large marine ecosystem of the shelf areas in the Gulf of Guinea: long-term variability induced by climatic changes. In: Sherman $K$, Alexander LM, Gold B (eds) Large marine ecosystems - stress, mitigation and sustainability. American Association for the Advancement of Science, Washington, p 104-118

Blaber SJM, Brewer DT, Harris AN (1994) Distribution, biomass and community structure of demersal fishes of the Gulf of Carpentaria, Australia. Aust J Mar Freshw Res 45: 375-96

Blache J, Cadenat J, Stauch A (1970) Clés de détermination des poissoins de mer signalés dans l'atlantique oriental entre le $20^{\circ}$ parallele nord et le $15^{\circ}$ parallele sud. Faune Tropicale XVIII, ORSTOM Editions, Paris

Brown BE, Brennan JA, Grosslein MD, Heyerdahl EG, Hennemuth RC (1976) The effect of fishing on the marine finfish biomass in the Northwest Atlantic from the Gulf of Maine to Cape Haterras. Int Comm Northwest Atl Fish Res Bull 12:49-68
Caddy JF, Sharp GD (1986) An ecological framework for marine fisheries investigations. FAO Fish Tech Pap 283, FAO, Rome

Caverivière A (1991) L'explosion démographique du baliste (Balistes carolinensis) en Afrique de l'ouest et son évolution en relation avec les tendances climatiques. In: Cury $\mathrm{P}_{\mathrm{r}}$ Roy C (eds) Variabilité, instabilité et changement dans les pêcheries ouest africaines. ORSTOM Editions, Paris, p 354-367

Cushing DH (1980) The decline of the herring stocks and the gadoid outburst. J Cons Int Explor Mer 39:70-81

Fager EW, Longhurst AR (1968) Recurrent group analysis of species assemblages of demersal fish in the Gulf of Guinea. J Fish Res Board Can 25(7):1405-1421

Fischer WG, Bianchi G, Scott WB (1981) FAO species identification sheets for fishery purposes. Eastern Central Atlantic fishing areas 34, 47 (in part), 7 vols., FAO, Rome

FishBase (1998) FishBase 98 CD-ROM. International Centre for Living Aquatic Resources Management (ICLARM), Manila

Gauch HG Jr (1994) Multivariate analysis in community ecology. Cambridge Studies in Ecology, Cambridge University Press, Cambridge

Gulland JA, Garcia S (1984) Observed patterns in multispecies fisheries. In: May RM (ed) Exploitation of marine communities: a report of the Dahlem workshop on exploitation of marine communities, 1-6 April 1984, Berlin. Springer, Berlin, p 155-190

Hill MO (1979) TWINSPAN. A FORTRAN program for arranging multivariate data in an ordered two-way table by classification of the individuals and attributes. Cornell University, Ithaca

Hill MO, Gauch HG (1980) Detrended correspondence analysis: an improved ordination technique. Vegetatio 42:47-58

Koranteng KA (1984) A trawling survey off Ghana, CECAF/ TECH/84/63. Dakar, Senegal. CECAF Project (FAO), Dakar, Senegal

Koranteng KA (1998) The impacts of environmental forcing on the dynamics of demersal fishery resources of Ghana. $\mathrm{PhD}$ thesis, University of Warwick

Longhurst AR (1969) Species assemblages in tropical demersal fisheries. In: Proceedings of the symposium on the oceanography and fisheries resources of the tropical Atlantic. Results of ICITA and GTS, 20-28 October 1966, Abidjan, Ivory Coast. UNESCO, Paris, p 147-168

Macpherson E, Gordoa A (1992) Trends in the demersal fish community off Namibia from 1983 to 1990. S Afr J Mar Sci 12:635-649

Mahon RR (1985) Groundfish assemblages on the Scotian shelf. In: Mahon RR (ed) Towards the inclusion of fishery interactions in management advice. Can Tech Rep Fish Aquat Sci 1347:153-162

Mahon RR, Smith W, Bernstein BB, Scott JS (1984) Spatial and temporal patterns of groundfish distribution on the Scotian shelf and in the Bay of Fundy, 1970-1981. Can Tech Rep Fish Aquat Sci 1300

Mensah MA, Koranteng KA (1988) A review of the oceanography and fisheries resources in the coastal waters of Ghana. Marine Fisheries Research Report No. 8, Fisheries Research \& Utilization Branch, Tema

Overholtz WJ, Tyler AV (1985) Long-term response of the demersal fish assemblages of Georges Bank. Fish Bull 83(4):507-520

Oviatt CA, Nixon SW (1973) The demersal fish of Narragansett Bay: an analysis of community structure, distribution and abundance. Estuar Coast Mar Sci 1:361-378

Pezennec O (1995) Ecological importance of the Ivorian and 
Ghanaian minor upwelling season. In: Bard FX, Koranteng KA (eds) Dynamics and use of Sardinella resources from upwelling off Ghana and Ivory Coast. ORSTOM Editions, Paris, p 324-345

Pinkas L, Oliphant MS, Iverson ILK (1971) Food habits of albacore, bluefin tuna and bonito in California waters. Fish Bull Calif Dep Fish Game 152:1-105

Ramos AR, Yraola IS, Peralta LF, Jimenez JFG (1990) Informe de la Campana Guinea 90. Instituto Español de Oceanografia, Malaga

Rijavec L (1980) A survey of the demersal fish resources of Ghana. CECAF/TECH/80/25, CECAF Project (FAO), Dakar, Senegal

Schneider W (1990) Field guide to the commercial marine resources of the Gulf of Guinea. FAO species identification sheets for fishery purposes. RAFR/F1/90/2, FAO, Rome

Sherman K (1993) Large marine ecosystems as global units for marine resources management-an ecological perspective. In: Sherman K, Alexander LM, Gold B (eds) Large marine ecosystems - stress, mitigation and sustainability. American Association for the Advancement of Science, Washington, p 3-14

Sissenwine MP, Brown BE, Palmer JE, Esig RG, Smith S (1982) Empirical examination of population interactions for the fishery resources off the Northeast USA. In: Mercer MC (ed) Multispecies approaches to fisheries management advice. Can Spec Publ Fish Aquat Sci 59:82-94

Editorial responsibility: Otto Kinne (Editor),

Oldendorf/Luhe, Germany
Smilauer P (1992) CANODRAW. Microcomputer Power, Ithaca Southwood TRE (1988) The concept and nature of the community. In: Gee JHR, Giller PS (eds) Organization of communities: past and present. Blackwell Science, Oxford

Stromme T (1992) NAN-SIS. Software for fisheries survey data logging and analysis. User's manual. FAO Computerized Information Series (Fisheries) 4. FAO, Rome

ter Braak CJF (1991) CANOCO-a FORTRAN program for canonical community ordination by [partial] [detrended] [canonical] correspondence analysis, principal component analysis and redundancy analysis (version 3.10). ITI-TNO, Wageningen

Tyler AV, Gabriel WL, Overholtz WJ (1982) Adaptive management based on structure of fish assemblages of northern continental shelves. In: Mercer MC (ed) Multispecies approaches to fisheries management advice. Can Spec Publ Fish Aquat Sci 59:149-156

van Tongeren OFR (1995) Cluster analysis. In: Jongman RHG, ter Braak CJF, van Tongeren OFR (eds) Data analysis in community and landscape ecology. Cambridge University Press, Cambridge, p 174-212

Williams F (1968) Report on the Guinean Trawling Survey. Org Afr Unity Sci Tech Res Comm 99, OAU/STRC, Lagos

Yáñez-Arancibia A, Sanchez-Gil P, Tapia Garcia M, GarciaAbad M de la C (1985) Ecology, community structure and evaluation of tropical demersal fishes in the southern Gulf of Mexico, Cahiers de Biologie Marine, Tome XXVI: 137-163

Submitted: May 30, 2000; Accepted: February 20, 2001

Proofs received from author(s): September 7, 2001 